Georgy Smirnov

\title{
THE ARCHITECTURAL IMAGE OF MOSCOW UNIVERSITY: A TEMPLE OF THE ENLIGHTENMENT OR A CITY MANOR?
}

The first ideas for creating a university in Russia came from Tsar Peter the Great, who discussed this with Leibniz. The great German philosopher suggested that the Tsar open universities in several cities, that is, in Moscow, St Petersburg, Astrakhan and Kiev, to include the important regions of the vast territory of Russian Empire ${ }^{1}$. One year before his death, on the 12 January 1724, Peter the Great founded the Academy of Sciences in St Petersburg, which should have included a university. But, actually, the latter did not operate properly. It was not until the mid- $18^{\text {th }}$ century, at the very beginning of the Enlightenment in Russia, that the first university was founded in Moscow. It was established at the initiative of, and according to the programme of, two prominent figures in Russian history - the scientist Mikhail Lomonosov and statesman Count Ivan Shuvalov, who both undoubtedly had the models of European universities in mind. Lomonosov had spent three years in Germany at Marburg University, where he studied under the guidance of the famous Christian Wolf. Count Shuvalov had A Description of Oxford University in his library, which had been published in 1675 and included 65

DOI: https://doi.org/10.12697/BJAH.2018.16.05

1 Sergei Shevyrev, Istorija Imperatorskogo Moskovskogo universiteta (Moscow: [s.n.], 1855), $4-5$. 
engravings of the views, perspectives and plans of Oxford and its colleges ${ }^{2}$.

Moscow University was opened based on a decree issued by Empress Elizaveta Petrovna, daughter of Peter the Great, which was signed on 25 January 1755. Since then, that day, Tatiana Day, has been celebrated by the students as their holiday, not only at Moscow University but all over Russia. It is worth mentioning that Empress Elizaveta Petrovna was treated by many educated persons of the day as a patroness of sciences and a prominent legislator. From the very beginning, the university bore the name of Elizaveta, but this was later forgotten and a less personal name adopted - the Moscow Imperial University.

Ivan Shuvalov was appointed to be the first curator of Moscow University, which was comprised of three faculties: philosophy, medicine and law. During the first years of the university's existence, a library and printing house were established, which published not only scientific papers and textbooks, but also an extremely popular Russian newspaper called Moskovskiye Vedomosti (Moscow News). From 1779 to 1789 , the university printing house was leased to a free-minded publisher Nikolai Novikov, who was a prominent representative of the liberal Russian intellectual movement of the time. From the very beginning, Moscow University became a significant cultural and educational centre of the Russian Empire. It was by no means a matter of chance that this centre appeared in the old Russian capital associated with a kind of Fronde, as opposed to St Petersburg, the young imperial capital. Although Moscow had ceased to be the capital of the empire, it still remained an intellectual, spiritual and cultural centre of the great country. No doubt there were also some practical and prosaic reasons that were included in the Empress's order for the establishment of the university ${ }^{3}$. These reasons included, firstly, Moscow's location in the central region of European Russia, inhabited by a large number of gentry and representatives of various other strata of society; secondly, lower living costs; and finally, many self-styled tutors, mostly foreigners, who were actually servants, hairdressers, etc. They were now to be replaced by the university graduates.

2 Irina Kulakova, Universitetskoe prostranstvo i ego obitateli. Moskovskij universitet v istorikokul'turnoj srede XVIII veka (Moscow: Novyi khronograf, 2006), 50.

3 Shevyrev, Istorija Imperatorskogo Moskovskogo universiteta, 11. 
At first, the university occupied the former building of the Main Pharmacy located close to the Kremlin's walls on the edge of Red Square - the historic centre of Moscow since the Middle Ages. It had been built around 1700 and bore signs of the Late Mannerist style popular in Moscow during the early years of Peter the Great's reign. This kind of architecture had nothing to do with the ideas of the Enlightenment, which demanded quite another aesthetical approach to an institution as important as a university. On the other hand, the location of the university was by no means inconvenient, as Red Square was the most significant and popular public place in the old Russian capital. It is also worth mentioning that the Main Pharmacy was not merely a medical institution, but a centre for the natural sciences as well. A chemical laboratory, a library and collections of plants and minerals were located here. Besides, the first Russian secondary school, the so-called Slavo-Graeco-Latina Academia, had existed on the adjacent Nikolskaya Street since 1687, and Mikhail Lomonosov was one of its graduates. Thus, the first building of Moscow University and its location were closely connected to the educational institutions of the recent period.

A year after the establishment of the university, a house owned by Prince Repnin, situated opposite the Kremlin on Mokhovaya Street, was bought by the crown for the new institution. This was one of the residential areas, with an impressive frontage of city manors, that had been inhabited since ancient times by the prominent aristocratic families of Russia, almost all of which were connected to the wives of the tsars - the Streshnevs, Naryshkins and Apraksins among them. By the mid-18 ${ }^{\text {th }}$ century, these manors included stone or brick houses with private churches in some of them. A series of impressive manors overlooked the picturesque Neglinnaya River Valley and the monumental Kremlin with its medieval fortifications beyond it. Since the $15^{\text {th }}$ century, the Neglinnaya River Valley has served as a military springboard west of the Kremlin. A wide strip of empty land between the river and the residential area, which was devoid of buildings, can be seen on the city plans of Moscow dating from the late $16^{\text {th }}$ and early $17^{\text {th }}$ centuries ${ }^{4}$. Despite the prohibitions that were in place, this territory was gradually built up. A part of it was occupied by the

4 Published in: Pamjatniki architektury Moskvy: Kreml, Kitai-gorod. Tsentralnyje plosjtjadi, ed. by Michail V. Posochin (Moscow: "Iskusstvo", 1982), 50-51, 54-59. 
pharmacy garden. And the Church of St Nicholas was erected opposite the Trinity Tower of the Kremlin. During the $17^{\text {th }}$ century some new buildings appeared, included shops and the houses of soldiers. In 1707, in connection with the Great Northern War with Sweden, the walls of the Kremlin and of the trading area of Moscow were reinforced with earth fortifications and a series of bastions based on Vauban's system of ramparts.

Returning to the history of Moscow University, we now arrive at the era of Catherine the Great, the empress who ruled from 1762 to 1796. During this time the Russian Enlightenment blossomed. The university was now treated as a temple of science. Its buildings were to be sumptuous and triumphal in character, representing the embodiment of the Temple of Minerva. In light of this concept, Minerva was regarded by the educated people of the day not only to be the goddess of wisdom, but was also associated with science and education, and with Catherine the Great. The latter was portrayed as Minerva in numerous works of art - in painting and sculpture, and also in a statue crowning the building of the Academy of Fine Arts in Saint Petersburg.

During the early years of Catherine's reign, the university still occupied Prince Repnin's former house and grounds, which were edged by Mokhovaya Street on the south, Nikitskaya Street on the west, and by neighbouring sites that included three ancient churches. Naturally, the large three-storied Repnin's house was not suited for its new educational needs and its grounds were too small to serve as the university's territory. Gradually, during the second half of the $18^{\text {th }}$ century and early $19^{\text {th }}$ century, the adjacent sites were bought by the crown and added to the original plot. All the buildings standing there, including the aforementioned churches, were torn down or totally reconstructed. A lane parallel to Mokhovaya Street was removed, and later, partly built over.

After the purchase of Repnin's former house, the most significant item on the agenda was its reconstruction, or rather replacement by a new building. The first new brick building was constructed near Repnin's house and its pediment was decorated with gilded wooden figures of the Muses, patronesses of the sciences and arts, which indicated the status of the institution. But this was hardly enough to satisfy the dignity of the university and its needs. 
The design of a new building appropriate for Moscow University was commissioned from Matvey Kazakov, the first-rate Moscow architect of the neoclassical period, which lasted from the 1770s to the 1800s. He began his work soon after 1777. During following decade, he produced three versions of the floor plans and elevations. ${ }^{5}$ All three projects demonstrated a very distinctive and complicated approach, which was inspired by the designs of the traditional European city palaces that were popular in Moscow during two last decades of the $18^{\text {th }}$ century. The plans comprised a main block - Corps de Logis - with two equal wings and corner pavilions symmetrically projecting from both sides, thereby creating a spacious cour d'honneur. The insides of all three versions were identical to a great degree. The central part of the main building was occupied by a grand hall, with two round rooms situated in the corner pavilions and two rows of rooms in the lateral wings divided by a narrow corridor. However, there were also significant differences.

The first project was the most complicated with two additional inner courtyards, incorporated between the Corps de Logis and lateral wings, connected by curved galleries. The main focus of the design was the central block of the building with its round and domed conference hall. The building had four staircases, symmetrically situated, with none of them designated as the main one. The central section of the facade, which corresponded to the hall, was given a very sumptuous treatment. It had a loggia with four truncated Ionic columns and was adorned with a large number of allegorical statues representing the sciences and education. The dome was crowned with a figure of the Archangel Michael, blowing a trumpet and bringing good news and good wishes for the cause of education and the flourishing of science. Rich sculptural decorations and a dynamic silhouette were characteristic of the Baroque tradition, which still wielded quite a strong influence in Moscow architecture during the early years of Catherine the Great's reign. Unlike the Corps de Logis, the elevations of the wings were plain, with pilasters and small pediments, and looked very much like the wings and annexes of Moscow's neoclassical city manors.

Kazakov's second version of the plans for Moscow University was much stricter and its general plan closer to what is seen as a

5 Russian State Military History Archive [Rossiiskii gosudarstvennyi voenno-istoricheskii arkhiv, RGVIA], 418-1-404, 5-10, 19-24; A. Kiparisova, 'Neopublikovannye proekty moskovskich zodčich konca XVIII i načala XIX vekov', Arhitekturnoe nasledstvo, 1 (1951), 111-114. 
typical Moscow manor house. The cour d'honneur was outlined more distinctly, using only straight lines. More attention was paid to the central block. The main staircase led to a huge oval hall treated as an amphitheatre, reminiscent of Antiquity, and corresponding to the idea of the Temple of Minerva. Both elements - the hall and the staircase - formed the central block of the building and stressed the main axis of the ensemble. The elevations of the lateral wings and corner pavilions were similar to the previous project, but the central part was altered quite decisively, though a colonnaded loggia was still preserved. The dome was flattened and the structure was deprived of most of the sculptures. Only two statues were left. One was of Minerva, associated directly with Catherine the Great - a monogram of the Empress was on a shield held by the goddess. The second was a Muse with a globe, an attribute of science. And some putti were placed on the attic. Thus, in the second version, Kazakov created a piece of architecture more appropriate to neoclassicism, with no Baroque reminiscences.

The new features were improved in the final version of the design. The floor plan was generally similar to the previous version, only stricter and more compact. The conference hall and the main staircase remained on the central axis, but their places were reversed: the former was now situated in front of the latter. The shape of the hall was also altered - its frontage became rectangular and the rear, semi-circular, echoed by a semi-circular colonnade. The hall was flanked by two similar long galleries - one for the library, the other for the mineral collection (in fact, for a museum of natural history). Both were surrounded on all sides by colonnades that supported the balconies.

On the outside, the central part of the building was emphasized by a portico with a series of eight Ionic columns that corresponded exactly to the width of the hall that was located behind them. The columns supported a classical entablature, surmounted by an attic with round openings. The dome at the top of the structure seems very flat, but actually, only the upper portion is visible from outside, and the larger part is hidden by a stepped crowning of the attic. The sculptural decorations were limited to two sitting figures of Minerva and a Muse with spears flanking the coat of arms of the Russian Empire. The final facade of Kazakov's project looked very harmonious and maintained the balance between verticality and horizontality. It was dignified, 
marking the status of the educational institution in the Age of Reason. A truncated column stood in the middle of cour d'honneur on the main axis of the ensemble, which was interrupted by a block with a sundial and topped by a globe - two vivid symbols of science and education.

The construction of the university building started in 1782 and was based on the first version of Kazakov's design. The left wing was completed in the same year, and in 1784, the right wing was ready. But the cornerstone for the Corps de Logis was not laid until 1786 and it was completed, based on the final version, during the next seven years ${ }^{6}$. An inauguration ceremony took place in the conference hall on 23 August 1793. The lecturers' speeches compared Moscow University to the Temple of Minerva - and this theme was never forgotten by the contemporaries.

However, one more aspect of the ideological concept related to Moscow University should be discussed. Two years before the inauguration, the Church of Saint Tatiana was consecrated in the corner pavilion on the east side of the building. In his speech, Plato, the Moscow Metropolitan, a highly educated and broad-minded person, said that the school of science and the school of Christ were now being combined, lay wisdom would be holy wisdom, and the small light and the great light coming from the single Father of Light, i.e. the Lord, would become one. This sophisticated combination of science and religion, of education and faith was probably one of the salient features of the Enlightenment in Russia.

The interior of the university church displayed the same dual character. On the one hand, the iconostasis, a necessary and traditional attribute of any Russian Orthodox church, was comprised of ancient icons taken from a neighbouring old church, which had been demolished. On the other hand, the architectural structure of the church had nothing to do with the Russian ecclesiastical tradition as it was built in a form of a rotunda topped by a dome. The altar resembled a small round temple with eight Corinthian columns, which supported a dome, crowned with a figure of the resurrected Christ. It should be also mentioned that the divine services were an integral part of the university's life and that icons hung on the walls of all the living rooms and classes.

6 Pamiatniki arkhitektury Moskvy. Bely̌ gorod, ed. by Gleb Makarevich (Moscow: "Iskusstvo", 1989), 99-102. 
The general architectural composition of Moscow University may be regarded as an embodiment of the French scheme referred to as entre cour et jardin, which was extremely popular in Moscow city manor architecture of the late $18^{\text {th }}$ century. A vast cour d'honneur in front of Corps de Logis was separated from the street by a stone fence with an iron grille, interrupted by two lateral gateways. At the rear of the building, a garden was planted, the traces of which can still be seen today. In light of the ideas of the Enlightenment, the environment of the university was treated as an important educational element. The garden could serve as a place for philosophical meditations and contemplation?

According to the general plan of Moscow, which was adopted in 1775, an open square surrounded by public and administrative buildings was to be installed in front of the university. The side opposite the university was left open to the Kremlin and the ponds of the Neglinnaya River. All three versions of Kazakov's project took this urban situation into account. Nevertheless, the square was never built and the surrounding area has remained rather picturesque. In the late $18^{\text {th }}$ century between the Kremlin walls and the Neglinnaya River one could still see the early $18^{\text {th }}$ century earth fortifications and numerous dwellings and shops that stood in front of the university. Thus, an open space between the ancient fortress and an impressive new building, which was meant to fit the general plan of Moscow, was not created. Instead of a regular neoclassical urban structure, the picturesque Neglinnaya River Valley dominated the panorama visible from the walls of the Kremlin ${ }^{8}$. In this urban landscape the university building looked like another city manor, though a larger one than its neighbours.

In regard to how the original architectural image of the university building looked in the late $18^{\text {th }}$ century, I would like to answer the question asked in the title of this article as follows. On the one hand, the university and its picturesque surroundings were very similar to the neoclassical Moscow city manor houses of the time. On the other hand, such architectural features, as the conference hall and

7 Kulakova, Universitetskoe prostranstvo i ego obitateli. Moskovskij universitet v istorikokul'turnoj srede XVIII veka, 231-232.

8 This panorama is seen on a drawing 'A view of Moscow University across the Neglinnaya River': Schusev State Museum of Architecture [Gosudarstvennyi nauchno-issledovatelskii muzei arkhitektury imeni A.V. Shchuseva, GNIMA], P-I 10943. 
allegorical programme of the sculptural decoration, transformed the university building an embodiment of the Temple of Minerva, i.e. a temple of the Enlightenment.

The architectural history of Moscow University did not end in the late $18^{\text {th }}$ century. The next significant period is connected with the Napoleonic invasion, the 1812 Fire of Moscow when the city was occupied by French troops, and the glorious victory over Napoleon. During the great fire, the university building burned down, as did most of the houses in Moscow. All that survived of Kazakov's ensemble, and of the older buildings behind it, were ruined walls without any floors or roofs. The conference hall, the library and the museum were totally destroyed. The restoration and rebuilding of the university began in 1817 and was completed by 1820 .

The main building of the university, as it was restored after the great fire and as it looks today, was created by Giacomo Gilardy, who had come from the canton of Ticino in Switzerland and was one of the most popular and prolific architect in Moscow at that time. He was assisted by a Russian architect, Dormidont Grigoryev, who also supervised the construction. In comparison to the original university building, the restored one essentially remained true to the floorplan and arrangement, but its outdoor and indoor decorations changed to great degree 9 . The outlines of the floor plan and main inner walls were not altered, although the ceilings and vaults were replaced, since they had been destroyed by the fire. On the frontage and the lateral elevations, all the horizontal divisions, vertical accents, recesses and projections remained the same, but the exterior decorations were totally replaced by new ones. The subtle articulation of the walls in the old building was replaced by lapidary decorative elements standing out against a plain surface. The quiet and balanced composition of Kazakov's project gave way to a more monumental and severe structure. All these new features engendered a spirit of the Empire style in the university building, which was extremely popular throughout Russia during the three decades after the war of 1812. It reflected the victorious inspiration that dominated a major portion of Russian society at a time when the university was being reconstructed.

9 Russian State Historical Archive [Rossiiskii gosudarstvennyi istoricheskii arkhiv, RGIA], 733-96-324, 326, 327, 338. 
The new character is seen most vividly in the pedimented central section of the facade crowned with an attic and a dome. The portico rests on a monumental basement with an open staircase and has Doric columns that are more indicative of a heroic masculine image of a glorious warrior than the 'feminine' Ionic order of Kazakov's project. In comparison to the latter, the intercolumniation of the portico, which was comprised of the same number of columns, was made wider. Thus, the portico occupied a larger area of the wall, and extended beyond the width of the conference hall behind it. The same feeling of monumentality, though on a much smaller scale, was expressed on the facades of the corner pavilions. Here the central axis is marked with a heavy aedicule with two Doric columns supporting an entablature.

The heroic theme was also reflected in the sculptural reliefs on the walls. At the time, the head of Medusa, the lions' heads, torches, wreaths and garlands were associated with heroic deeds, military glory and victory. The six-pointed star, the star of King David who had defeated Goliath, was repeated several times on the walls and was meant evoke Tsar Alexander I's victory over Napoleon. No less significant were the sculptural images connected to the themes of science, art and education. A three-partite frieze situated between the columns of the portico represents the Nine Muses who embody the sciences and arts. It was executed by Gavriil Zamaraev, a prominent Moscow sculptor and a pupil of Jean-Baptiste Pigalle, according to the Gilardy's drawings.

Though the university was fundamentally reconstructed, the wall articulation of Kazakov's building was left almost intact on the rear facade. Here one can still see the monotonous vertical rhythm of the shallow recesses with windows on three stories. But, I believe the cornice mouldings were added by Gilardy.

As mentioned above, great changes were made inside the university building, although much of its original floor plan was preserved. As was the case with the exteriors, the interiors were also given a new character that corresponded to the Empire style. In this respect, two indoor spaces are worth discussing. Firstly, the vestibule situated on the main axis of the first floor behind the entrance from the cour $d^{\prime}$ honneur and in front of the staircase leading to the second floor. In comparison with the vestibule of Kazakov's project, which was built as a hall with a semi-circular colonnade, Gilardy's solution is a long 
dark corridor. It is flanked by two rows of Doric columns, supporting a low ceiling, the walls have no windows, and the floor is covered with heavy cast-iron slabs. Thus, the vestibule makes a solemn but rather gloomy impression, probably in anticipation of the magnificent, light-filled and airy conference hall, which has been wonderfully preserved until the present day. One enters this exciting interior by climbing a modest, but well-proportioned and artistically articulated staircase, passing through the entrance adorned with a portico framed by two pairs of Ionic pilasters. The pediment is covered by excellent quality stucco work. The frieze of foliage includes two helmets and a lyre as the attributes of Minerva and Apollo, thus expressing a dual ideological meaning apparent in the architecture of the building - the military glory of the recent victory and the glorification of arts and sciences. Both themes continue in the decoration of the conference hall itself.

The solemn space of the hall preserves the shape of its predecessor in Kazakov's building, but it is six and a half meters higher. The front of the hall is pierced with five openings, correspondent to the width of six of the eight-column portico. The semi-circular rear of the hall is marked with a colonnade with the same curved shape. A splendid Ionic colonnade bears an entablature topped with the balustrade of the balcony. The space above is covered with a halfdome. The opposite, windowed side of the hall is surmounted with a huge barrel vault. All these constructive elements play a great role in creating an impressive hall, full of dignity and subtle spacing. No less important is the illusionistic sepia-like grisaille painting covering most of the walls and vaults. It includes figurative compositions, single allegorical images and ornamental motifs. A long multi-figural frieze, dedicated to the glorification of sciences and arts, dominates the semi-circular wall behind the colonnade. The numerous personages of Ancient Greece who are depicted include Socrates, Homer, Phidias, Hippocrates and Callicrates; and from more modern times, we see Galileo Galilei. On the opposite wall, a large lunette is covered by a composition with Apollo in the centre, who is presented as a patron of arts, sciences and education. In the numerous other smaller compositions and images that cover the vaults, the theme of the arts and sciences dominates. However, we find several compositions related to military attributes, such as armour, weapons and shields. As both themes are treated in terms 
of Antiquity, ancient history and mythology, the general character of the murals seems very organic. But a detailed investigation of its programme is still waiting to be conducted ${ }^{10}$.

By 1820 Gilardy and Grigoryev had reconstructed not only Kazakov's main building, but also rebuilt some of the former private mansions that had already belonged to the university for two or three decades. They were situated behind the main building and were occupied by the medical faculty of the university. The twostorey buildings of the medical institute and the hospital overlooked Nikitskaya Street. The one-storey anatomical theatre was located behind an oval-shaped garden with serpentine walks, actually an English garden in miniature ${ }^{11}$.

All three buildings are typical examples of post-fire Moscow architecture, reflecting the characteristic features of the Empire style $^{12}$. Thus, they fit the general urban concept of the reviving city, and together with the main building, create an architectural ensemble of a high artistic quality. On the floor plan for the anatomical theatre, one can clearly see the innovations added by Gilardy or Grigoryev to the old structure. They are marked in red and reveal a wonderful amphitheatre in the main anatomical auditorium.

The restoration of the university buildings was not a separate architectural project, but a part of the general urban reconstruction after the 1812 Moscow Fire. In the course of this reconstruction, a new situation developed at the university. Between 1817 and 1825, a long building for the manège. which was one of the finest Empirestyle buildings in Moscow, was erected practically in front of the university. Its main facade was supposed to anchor the lateral part of the square, which was to be arranged among the other squares around the Kremlin. But the project was not realised. Once again, an open space in front of the university was not created. The area was still occupied by commercial buildings and dwellings, which separated the university from the Kremlin and its adjacent territory. This changed quite a lot after the fire of 1812 . The early $18^{\text {th }}$ century earth fortifications were levelled and the Neglinnaya River was

10 A brief survey of the program is provided in: Vladimir Kirillov, 'Moskovskii universitet (istoria stroitelstvo i rekonstrukcii)', Matvei Fedorovich Kazakov i arkhitektura klassitsizma, ed. by M. Mikhailova (Moscow: NII teorii arkhitektury i gradostroitel'stva, 1996), 46-47.

11 RGIA, 733-96-323.

12 RGIA, 733-96-329, 335, 336, 344. 
directed into a tunnel. In their place, a charming picturesque garden was installed, which was later named the Alexandrian Garden after Tsar Alexander I. It was surrounded by an iron fence adorned with Roman military attributes typical of the Empire style. On the way to Red Square, the fence was monumental in scale, but from the side facing the projected square, it was much lower in order to establish a visual connection with the university. But unfortunately it was not put into effect because of a great building density, which still survived and even was extended on this territory.

The last phase of the Enlightenment related the architectural and urban development of Moscow University dates from the 1830s. During those years, its territory was almost doubled by purchasing the neighbouring mansion of the Pashkov family, which was situated on the opposite side of Nikitskaya Street ${ }^{13}$. The house behind the cour d'honneur and the manège annex, which stretched along Nikitskaya Street, had been built in 1790s. The architecture had much in common with the buildings designed by Kazakov for the university and probably built according to his plans. The house had an impressive central section with a portico and belvedere. On the narrow frontage, the manège was emphasized with a colonnaded half-rotunda with a flat dome. Almost a half century later, these architectural forms were naturally outdated. The newly purchased buildings had to fit the Empire-style architecture of the main building. This task was fulfilled by famous Moscow architect Evgraf Turin.

His original project, which was completed in 1832, was rather ambitious and created a complete and balanced two-partite ensemble ${ }^{14}$. Firstly, both sections - the old and the new - were connected by a gallery spanning Nikitskaya Street at a first-floor level. Secondly, the former Pashkov's house was flanked by two wings similarly to the old university building. The corner pavilions with rounded edges were treated in the same way. The right wing was rebuilt from the former manège and was to serve as a dormitory. The new left wing was comprised of rooms for the students' leisure activities. Thirdly, in order to achieve complete symmetry on the general facade, Turin projected an additional building for the laundry to the left side of the building. Already in 1822 the pharmacy house was erected on

13 Pamiatniki arkhitektury Moskvy. Belyi gorod, 102-104. 
the right side of the university. Fourthly, the architectural forms of the rebuilt and newly erected structures were almost the same as of the old section of the university, closely replicating its horizontal divisions and vertical accents, not to mention the similar wall decorations.

This project was not executed in full. The gallery over the street was never built and the symmetry of the general facade was not achieved. I do not know whether a laundry building was erected or not. But what is more important, regardless of the design, the right wing (the former manège) was treated as a very impressive element of the entire structure. This alteration in the original plan was caused by the new position of the university church dedicated to Saint Tatiana. Originally, it was to be added as a central projection at the rear of the main building. Later it was decided not to hide the church behind the building, but to place it at the centre of the frontage, in place of the former manège, where it was consecrated in 1837.

This was probably orchestrated by Sergey Uvarov, the Minister of Education and President of the Academy of Sciences, and propagandist of the state ideology of 1830s, which was called 'official nationality'. It was Uvarov, who authored the official motto for this ideological concept, namely 'Orthodoxy. Autocracy. Nationality'. This expression put orthodoxy in first place, indicating the increasing significance of the Orthodox Church in the life of Russian society during the reign of Nicholas I (1825-1855). I believe that was the reason for the basic alteration of the original project. And a result, one of the most remarkable elements of the entire university ensemble was created based on a new design by Turin.

The new task enabled Turin to preserve the structure of a halfrotunda of the former manège wing. It now became part of the altar, which in most Russian Orthodox churches is semi-circular shape. A large section of the building behind the altar was occupied by a church hall and a very impressive staircase leading from the ground floor to the vestibule of the church. The colonnades and heavy entablatures with sumptuous stucco-work create a solemn atmosphere in the vestibule. The hall of the church is topped by a dome supported by pendentives and four great arches, thereby filling the space with light and air. The altar is separated by a low colonnaded iconostasis with gilded details. It is topped by the sculptures of the crucified Christ and two kneeling angels who are clearly visible against the 
background of the light blue sky painted on a half-spherical vault of the altar.

On the outside, a monumental Roman Doric colonnade with stucco decorative motifs above the windows complement the stylistic forms of the other university buildings. The ecclesiastical function of the building is indicated only by a cross on the front edge of the roof and an inscription saying: 'The light of Christ enlightens everyone'. A similar inscription is on the entablature of the iconostasis under the Crucifixion: 'Come to him and be enlightened'. Thus, Filaret, the Moscow Metropolitan, who is the author of these inscriptions, associates enlightenment related to civil education with the Christian doctrine, or more accurately, subjugates education to religion. Actually, this marked the end of the Age of Enlightenment.

The Empire-style university ensemble, with an architectural image of its dual nature, i.e. that of 'a temple of the Enlightenment' and of 'a city manor', did not last long. During the second half of the $19^{\text {th }}$ and the early $20^{\text {th }}$ century, all the buildings, except for the main one, were reconstructed or replaced by new buildings in the eclectic revivalist style. The former Pashkov's house was rebuilt in the neoclassical style of early $20^{\text {th }}$ century.

All that remains to be said is a few words about the subsequent urban history of Moscow University. By the end of the $19^{\text {th }}$ century, the building density around it increased markedly both along the main frontage and on Nikitskaya Street. The old university buildings were almost squeezed out by new buildings.

The situation changed considerably during the Soviet era. By 1938 all the buildings between Alexandrian Garden and the university were demolished, thus creating an open space for a vast new square with good visual connections between the university, manège and Kremlin. During the perestroika years, thousands of people were able to gather there. I believe, this was the main reason the square was reconstructed again in 1990s. A recreational zone was created, which, to my mind, was executed in a very poor artistic taste. It destroyed the open space of the square and damaged the visual connections between the university and the Alexandrian Garden.

And yet, even today, we can observe the university's Empire-style ensemble in its glorious beauty. 
Georgy Smirnov: The Architectural Image of Moscow University: A Temple of the Enlightenment or a City Manor?

KeyWords: UniVersity of MOSCOW; UNIVERSITY ENSEMbLE; ARCHITECTURE; Enlightenment; Prince Repnin's house; Pashrov's house; Matvey Kazakov; Giacomo Gilardy; Dormidont Grigoryev; Evgraf Turin

Georgy Smirnov is the leading researcher at the Department of the Inventory of Historic Buildings at the State Institute for Art Studies in Moscow. He studied art history at the University of Moscow. In 2003, he received a PhD with a work titled Architecture of Public Buildings in Russian Provincial Towns in the 2 nd Half of the $18^{\text {th }}$ Century. His main fields of research are Russian $18^{\text {th }}$ century architecture (especially Baroque and Neoclassical) and Central Europe in the $16^{\text {th }}-18^{\text {th }}$ centuries. Smirnov has released numerous publications on the history of Russian architecture and Baroque architecture in Central Europe. Recent publications include: Inventory of Historic Buildings and Monuments of Russia. Tver Region (Svod pamyatnikov arkhitektury i monumentalnogo iskusstva Rossii. Tverskaya oblast), vol. 1-4 (ed. by G. K. Smirnov, 2003-2016); History of Russian Art, vol. 13. Russian Provincial Art of the second half of the $18^{\text {th }}$ Century (Istoriya rysskogo iskusstva, Tom 13. Provinzialnoe iskusstvo vtoroi poloviny 18 veka) (ed. by G. K. Smirnov, under completing). 